\title{
Further Section
}

Dermatologica, 1956;113:407

\section{Personalia}

Am 1. Dezember 1956 ist in Paris Dr. A. Sézary, der sich besonders um die Systematik der Retikulosen verdient gemacht hat, gestorben. 